\title{
Characterisation of charred organic matter in micromorphological thin sections by means of Raman spectroscopy
}

\author{
Glenn Lambrecht ${ }^{1}$ (1) C Caterina Rodríguez de Vera ${ }^{1} \cdot$ Margarita Jambrina-Enríquez $^{1,2} \cdot$ Isabelle Crevecoeur $^{3}$. \\ Jesus Gonzalez-Urquijo ${ }^{4}$ - Talía Lazuen ${ }^{3}$ - Gilliane Monnier ${ }^{5}$ • Goran Pajović ${ }^{6}$ - Gilbert Tostevin ${ }^{5}$ - Carolina Mallol ${ }^{1,7}$
}

Received: 26 August 2020 / Accepted: 14 December 2020 / Published online: 6 January 2021

(C) The Author(s) 2021

\begin{abstract}
Burned or charred organic matter in anthropogenic combustion features may provide important clues about past human activities related to fire. To interpret archaeological hearths, a correct identification of the organic source material is key. In the present work, Raman spectroscopy is applied to characterise the structural properties of char produced in laboratory heating- and openfire experiments. This reference data set is compared to analyses of three different archaeological sites with Middle Palaeolithic combustion contexts. The results show that it is possible to determine whether a charred fragment is the product of burning animal-derived matter (e.g. meat) or plant-derived matter (e.g. wood) by plotting a few Raman spectral parameters (i.e. position of $\mathrm{G}$ and $\mathrm{D}$ bands, and intensity ratios $H_{\mathrm{D}} / H_{\mathrm{G}}$ and $H_{\mathrm{V}} / H_{\mathrm{G}}$ ) against one another. The most effective parameters for discriminating animal- from plant-derived matter are the position of the $\mathrm{G}$ band and the $H_{\mathrm{V}} / H_{\mathrm{G}}$ intensity ratio. This method can be applied on raw sample material and on uncovered micromorphological thin sections. The latter greatly compliments micromorphology by providing information about char fragments without any clear morphological characteristics. This study is the first of its kind and may provide archaeologists with a robust new method to distinguish animal- from plant-derived char in thin sections.
\end{abstract}

Keywords (micro-)Raman spectroscopy $\cdot$ Char $\cdot$ Tar $\cdot$ Charcoal $\cdot$ Micromorphology $\cdot$ Archaeology $\cdot$ Fire $\cdot$ Pyrotechnology

\section{Introduction}

The identification of burned organic matter in anthropogenic combustion features is essential for interpreting archaeological

Glenn Lambrecht

glambrec@ull.edu.es

1 Instituto Universitario de Bio-Orgánica Antonio González (IUBO), Universidad de La Laguna, Santa Cruz de Tenerife, Spain

2 Departamento de Biología Animal, Edafología y Geología, Universidad de La Laguna, Santa Cruz de Tenerife, Spain

3 Université de Bordeaux, CNRS, UMR 5199 - PACEA, Pessac, France

4 Instituto Internacional de Investigaciones Prehistóricas de Cantabria (IIIPC), Universidad de Cantabria, Santander, Spain

5 Department of Anthropology, University of Minnesota, Minneapolis, MN, USA

6 National Museum, Cetinje, Montenegro

7 Departamento de Geografía e Historia, Universidad de La Laguna, Santa Cruz de Tenerife, Spain hearths (Mallol et al. 2017). Charred particles in particular may provide valuable clues about fuel, food or refuse from different human activities. To interpret a hearth's function correctly, it is crucial to be able to identify the source organic material from which those particles originated (e.g. bone, animal fat, wood, wood tar etc.).

Micromorphology has proven to be a reliable method for identifying mineral and organic components in combustion features (e.g. Nicosia and Stoops 2017). This method involves the observation of thin sections of undisturbed archaeological sediment through a petrographic microscope. As such, the spatial and stratigraphic relationship between components remains intact. Under the microscope, charred particles (hereafter referred to as 'char') appear opaque in transmitted light. The current practice is to classify char based on morphological criteria (Mallol et al. 2017). For example, char that is the product of wood combustion is identified by the presence of a cellular structure, reminiscent of woody tissues. This type of char is named 'charcoal'. Char fragments that have a vesicular structure and drop-like morphology have been interpreted by Goldberg et al. (2009) as the product of burned fat or flesh. This type of char is referred to as 'fat-derived char'. Recently, 
however, Huisman et al. (2019) have observed char with a very similar morphology attached to charcoal fragments, which they interpreted as solidified wood tar. This presents a problem within micromorphology: in the absence of supplementary information (e.g. presence of bones etc.), loose vesicular char fragments with drop-like morphology can either be interpreted as animal-derived matter (e.g. fat-derived char) or plant-derived matter (e.g. wood-derived tar), obviously changing the interpretation of hearth function. Also, when char fragments do not possess any clear morphological characteristics, identifying their organic source material is impossible without supplementary information. Thus, a purely micromorphological approach can in some cases not identify the origin of burned organics unequivocally.

Over the years, micromorphology has been complemented with other microscopy-based techniques, the sum of these methods often referred to as the 'micro-contextual approach' (Goldberg and Berna 2010). The current practice is to apply a combination of micromorphology, micro-Fourier transform infrared (FTIR) spectroscopy, and organic petrology. MicroFTIR probes the molecular structure of matter. Within the micro-contextual approach, it is applied to discriminate between burned and unburned bones and to identify inorganic soil components (e.g. Stiner et al. 1995; Goldberg and Berna 2010; Stahlschmidt et al. 2015; Villagran et al. 2017). To our knowledge, it has not yet been applied on char even though char spectra have been reported and published in geological sciences (e.g. Guo and Bustin 1998). Organic petrology is the study of carbonaceous matter in sediments (e.g. Taylor et al. 1998). Individual components are referred to as 'macerals' and studied under oil immersion with a petrographic microscope in reflected-optical and fluorescent mode (Ligouis 2017). Within the micro-contextual approach, organic petrology is able to confirm whether macerals are likely to be the product of burning (i.e. char) or of humification (e.g. Taylor et al. 1998; Goldberg et al. 2009; Stahlschmidt et al. 2015; Ligouis 2017; Villagran et al. 2017). While both micro-FTIR and organic petrology provide useful information, none of these methods - to this date - have been explored to distinguish animal- from plant-derived matter in archaeological contexts.

Other (non-microscopic) techniques, such as molecular and (compound-specific) isotopic analyses of archaeological sediment have recently also been applied to detect the presence of animal- or plant-derived matter in anthropogenic combustion contexts (e.g. Buonasera et al. 2019; Jambrina-Enríquez et al. 2019). While these techniques are powerful, they cannot be directly applied on individual microscopic char fragments in thin sections. They also require relatively large amounts (a few grams) of sample material, which in practice constrains their stratigraphic resolution to a centimeter scale.

In the present work, we explore Raman spectroscopy as a complementary technique to micromorphology for the characterisation of char in combustion features. As this method is also microscopy based, it is directly applicable on individual microscopic char fragments either as raw sample material or embedded in uncovered micromorphological thin sections. Our aim is to quantify and interpret differences between Raman spectra from different char types (i.e. chars derived from meat and wood of different animal and tree species). The present study thus focusses on identifying the source organic material from which char could be derived (i.e. animalor plant-derived matter).

\section{Background to Raman spectroscopy of char}

Raman spectroscopy is a laser-based microscopy technique that provides information about molecular structures by measuring the vibrational energies of covalent bonds between atoms (e.g. Smith and Dent 2005). Char and charcoal are products of heating biomass in the absence of air (i.e. carbonisation) or under conditions that have a limited supply of oxygen (i.e. incomplete combustion or charring) (Braadbaart and Poole 2008). They may also be referred to as 'pyrogenic organic matter' (Zimmerman and Mitra 2017) or 'black carbon' (Goldberg 1985). Black carbon encompasses a range of products: from slightly charred, degradable biomass, to highly condensed, refractory soot (Masiello 2004). Two mechanisms of formation can be distinguished, resulting in two fundamentally different molecular structures: a first mechanism entails a recombination of small molecules (volatiles) released by pyrolysis into larger molecules and polycyclic aromatic hydrocarbons (PAH). A few PAHs form stacks of about $0.1 \times 2 \times 2 \mathrm{~nm}$ (Heidenreich et al. 1968; Schmidt and Noack 2000). These stacks form a network of spheroidal units of about $20 \mathrm{~nm}$ in diameter (Heidenreich et al. 1968 ) which precipitate on a surface, forming aggregates. This type of char is commonly referred to as 'soot' (Kennedy 1997). The second mechanism is lesser known and involves an in situ transformation of the solid source material into progressively larger aromatic structures until a network of similar randomly oriented stacks is formed - the difference being that these stacks do not form spheroidal units. At a microscopic scale this char mostly retains the morphology of its precursor material (Schmidt and Noack 2000; Masiello 2004). While soot consists of mostly carbon (Kennedy 1997), charcoal produced at temperatures below $700{ }^{\circ} \mathrm{C}$ may still contain substantial amounts of oxygen and hydrogen (Cao et al. 2012).

The Raman spectra of char are mainly characterised by inplane vibration of carbon atoms in aromatic structures $\left(\mathrm{sp}^{2}\right.$ hybridisation). This vibration produces a peak at about $1575-1600 \mathrm{~cm}^{-1}$. In ideal graphite crystals, it is the only vibration that is Raman active and is called the ' $\mathrm{G}$ ' band- $\mathrm{G}$ standing for graphite. As chars consist of small stacks of PAHs oriented in all directions, they do not possess a crystal structure such as graphite. Heating chars to about 2500-3000 
${ }^{\circ} \mathrm{C}$, however, will slightly increase their crystallographic order but graphite will never form (Heidenreich et al. 1968; Bernard et al. 2010). In contrast, graphitisable carbons such as antracene-based cokes will transform to graphitic carbon and graphite over the same temperature range (Bernard et al. 2010). In char and graphitic carbon, a broad band at about $1350 \mathrm{~cm}^{-1}$ is also present. This band is broad in chars but narrower in graphitic carbons (e.g. Beyssac et al. 2003). It is caused by a double resonance effect created by defects in the ideal graphite structure (Thomsen and Reich 2000). This band is referred to as the ' $\mathrm{D}$ ' band-D standing for disorder (Tuinstra and Koenig 1970; Vidano and Fischbach 1978; Wang et al. 1990). In graphitic carbons, the positions of the $\mathrm{D}$ and $\mathrm{G}$ band, as well as the relative height of the $\mathrm{D}$ band compared to the height of the $\mathrm{G}$ band (i.e. the $\mathrm{D} / \mathrm{G}$ height ratio $\left.H_{\mathrm{D}} / H_{\mathrm{G}}\right)$ depends on the amount of defects in the graphitic crystal structure (e.g. Tuinstra and Koenig 1970; Vidano and Fischbach 1978; Wang et al. 1989; Beyssac et al. 2003), the size of the crystals (Tuinstra and Koenig 1970; Wang et al. 1990), the orientation of the crystal relative to the Raman laser beam (Wang et al. 1989) and the temperature and pressure of formation (e.g. Beyssac et al. 2002, 2003). In chars, lacking crystal structure, those parameters mainly depend on temperature of formation (e.g. McDonald-Wharry et al. 2013; Deldicque et al. 2016) and degree of degradation (e.g. Goler et al. 2019). Unlike the $G$ band, the $D$ band position is sensitive to the laser wavelength used so care should be taken when comparing Raman spectra of char acquired with different laser wavelengths (Vidano et al. 1981; Mernagh et al. 1984; Wang et al. 1990; Russo and Ciajolo 2015).

A number of papers have recently been published that are relevant to archaeology: exploiting the relation between $H_{\mathrm{D}} / H_{\mathrm{G}}$ and temperature of formation, Deldicque et al. (2016) proposed a palaeothermometre for wood-based chars. They show that with increasing burning temperature, $H_{\mathrm{D}} / H_{\mathrm{G}}$ ratios rise in a predictable manner. Dupin et al. (2019) applied this technique on micromorphological thin sections to characterise charcoal production platforms dating from the seventeenth to the twentieth century. Although char is considered to be chemically very stable, it can significantly degrade through oxidation and microbial activity over tens to hundreds of years (e.g. Bird et al. 1999). Such degradation may impact the Raman spectra, as suggested by Goler et al. (2019) who have shown that $H_{\mathrm{D}} / H_{\mathrm{G}}$ ratios in carbon-based inks from ancient Egyptian manuscripts decrease with increasing age of the manuscripts.

\section{Materials and methods}

\section{Samples}

Samples were divided into 'reference samples' (Table 1) and 'unknown samples' (Table 2). Reference samples contained char of known origin (plant- or animal-derived) and were further subdivided into samples produced in laboratory furnace experiments and samples produced in outdoor fire experiments. Unknown samples contained both plant- and animalderived char. In these samples, individual char fragments were interpreted to be of plant or animal origin through micromorphology (see 'Micromorphology'). Unknown samples were further subdivided into samples produced in outdoor fire experiments and archaeological samples. The latter were selected from three different sites: Axlor-Spain $\left(43^{\circ} 07^{\prime} 17^{\prime \prime} \mathrm{N}, 2^{\circ}\right.$ $43^{\prime} 41^{\prime \prime} \mathrm{W}$ ), Crvena Stijena-Montenegro ( $42^{\circ} 46^{\prime} 44.4^{\prime \prime \prime} \mathrm{N}$, $\left.18^{\circ} 28^{\prime} 51.6^{\prime \prime} \mathrm{E}\right)$ and La Roche-à-Pierrot-France $\left(45^{\circ} 45^{\prime}\right.$ $\left.1.9224^{\prime \prime} \mathrm{N}, 0^{\circ} 30^{\prime} 21.5968^{\prime \prime} \mathrm{W}\right)$, with Middle Palaeolithic combustion contexts for which hearth function and fuel sources are unknown. All samples were prepared as uncovered polished thin sections suitable for micromorphological analysis. In addition, some sample material from the furnace experiments (Table 1) was left unprepared to investigate effects of thin section preparation.

\section{Methods}

\section{Furnace experiments}

Xylem and bark samples (Table 1; Fig. 1) were prepared as follows: blocks of xylem tissue, of approximately $2 \times 3 \times 4 \pm$ $0.5 \mathrm{~cm}$, and weighing about $9-11 \mathrm{~g}$, were cut with a handsaw from a slice of a Pinus canariensis tree trunk. Three such blocks were made and each placed inside a porcelain crucible, covered with aluminium foil. Three such crucibles were prepared, one for each target temperature $\left(350,400\right.$ and $\left.450{ }^{\circ} \mathrm{C}\right)$. Fragments of bark were manually removed from the same slice of a Pinus canariensis tree trunk and broken into centimeter-sized fragments. Three crucibles (one for each above temperature) were filled with about $6.5 \mathrm{~g}$ of bark and covered with aluminium foil. Cow meat samples were prepared as follows: first, each porcelain crucible's interior was lined with aluminium foil to allow easy extraction of char after burning. Approximately $10 \mathrm{~g}$ of pure quartz sand (i.e. $\alpha$ quartz) was placed inside this crucible and one block of cow meat of about 16-21 g was placed on top of the sand. This way, any liquid residue produced during the experiment could be captured by the sand substrate. Then, the whole crucible was covered with aluminium foil.

Each filled crucible was weighed with a laboratory precision balance (error: $\pm 0.0001 \mathrm{~g}$ ) and subsequently placed inside a muffle furnace (model Nabertherm B180). The furnace was programmed to heat to the target temperature, applying a heating rate of $18-22{ }^{\circ} \mathrm{C} \mathrm{min}^{-1}$, and to keep that target temperature stable for $1 \mathrm{~h}$. A limited amount of oxygen was present inside the furnace so combustion of wood tissue likely occurred, temporarily adding some additional heat to the sample. As the muffle furnace did not feature an active cooling 


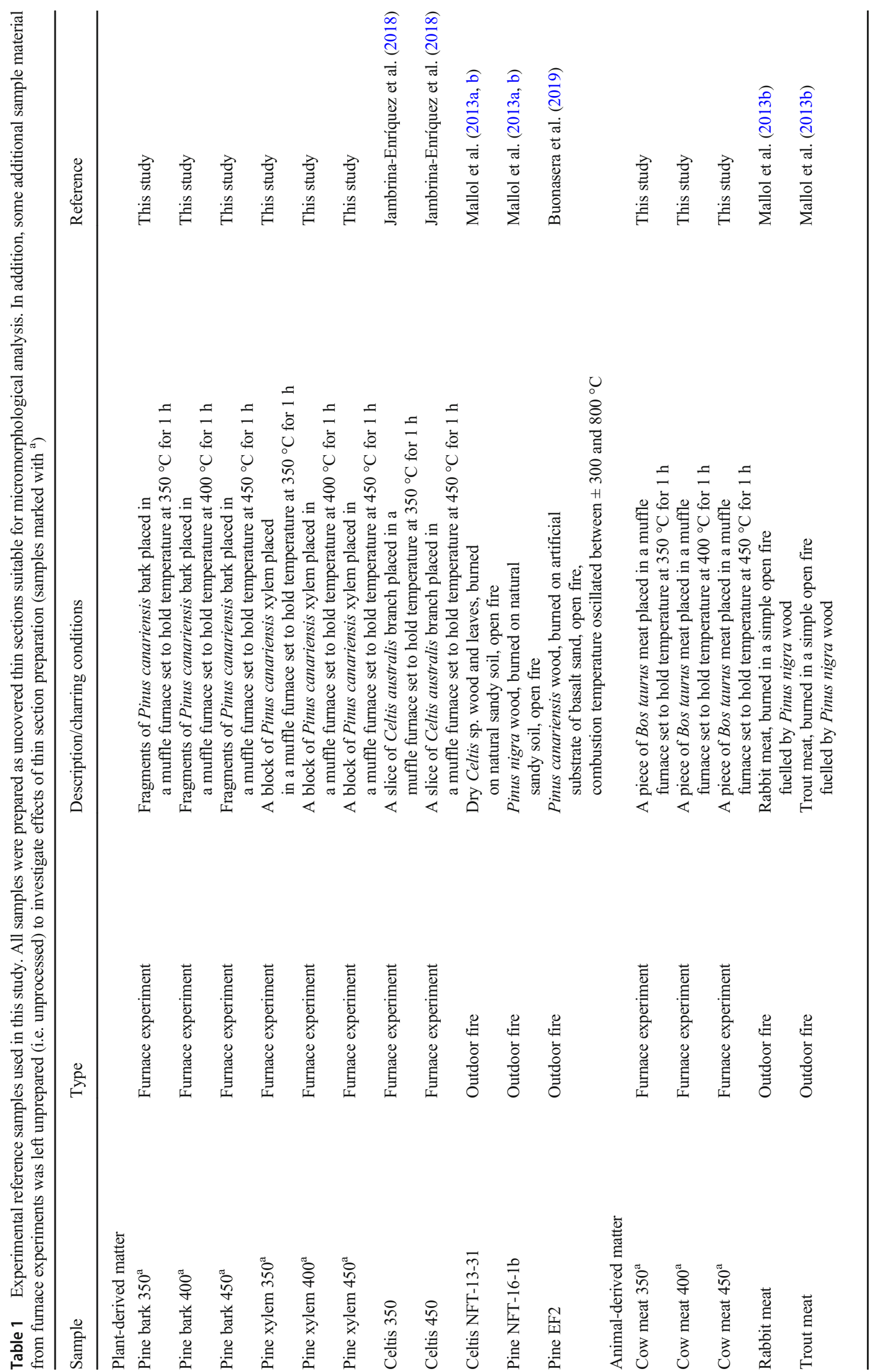


mechanism, the stated temperatures should thus be considered minimum approximations of actual sample temperature. After cooling to room temperature, each filled crucible was weighed again to record sample weight loss (see Table S1 in Online Resource for weight and temperature data). A small amount of char or charcoal was removed for (raw, unprocessed) analysis. The remaining material was embedded in a two-component epoxy resin and prepared as a polished thin section without covering glass using a precision cutting machine (ATMBrillant 2000) and grinding machine (G\&N MPS-RC).

The samples 'Celtis 350' and 'Celtis 450' (Table 1) were similarly prepared in a previous study (Jambrina-Enríquez et al. 2018).

\section{Outdoor fire experiments}

Modern outdoor 'NFT' fires, 'Rabbit meat' and 'Trout meat' (Tables 1 and 2) were created as part of the Neanderthal Fire Technology Project (Mallol et al. 2013a, b). The 'EF2' reference fire (Table 1) was created in another study (Buonasera et al. 2019).

\section{Micromorphology}

A Nikon AZ-100 petrographic microscope was used to characterise charred matter in unknown samples (Table 2). Criteria described in Mallol et al. (2017) were followed. Charred fragments with a clearly preserved anatomy of woody tissue were labelled 'charcoal'. Fragments with vesicles, cracks and droplike anatomy were labelled 'char'. When this type of char was attached to charcoal, it was labelled 'wood char' and when it was attached to burned bone, it was labelled 'bone char' (Fig. 2 ). The presence or absence of these char types in samples is given in Table 2.

\section{Raman spectroscopy}

Raman spectra were acquired with a Renishaw InVia ${ }^{\mathrm{TM}}$ confocal Raman microscope, located at the Department of Physics and IMN of the University of La Laguna (ULL), Tenerife, Spain. The samples were excited with a 532-nm (green) laser focused on the sample surface. The Raman signal was collected in backscattered mode using a 50x objective. Sampled volume was a few cubic micrometres, and power on sample was kept low at about $0.07-0.12 \mathrm{~mW}$ to avoid sample degradation. The diffraction grating was $1800 \mathrm{l} / \mathrm{mm}$, which produced spectral resolutions of $1.73 \mathrm{~cm}^{-1}$ per pixel. An initial set of 57 spectra was recorded from 200 to $4000 \mathrm{~cm}^{-1}$, and a later set of 108 spectra was recorded from 800 to $2300 \mathrm{~cm}^{-1}$ to cut back on overall measurement time. Acquisition time was 3 $\times 10 \mathrm{~s}$ for all spectra. For the reference samples, five measurements were made on each sample. For the unknown samples, for each sample location (i.e. modern, Axlor, Crvena Stijena 
and La Roche-à-Pierrot), up to five char fragments of each category (i.e. charcoal, char, wood char and bone char) were chosen, if able. Each char fragment was then measured twice.

Spectra were processed using the program PeakFit ${ }^{\mathrm{T}_{\mathrm{TM}}}$ v4.06 by AISN Software Inc. The procedure to extract spectral parameters was similar to the method described in Deldicque et al. (2016) and is shown in Fig. 3. After acquiring a raw spectrum, a section between 1000 and $1800 \mathrm{~cm}^{-1}$ was selected and a straight base line was drawn between the end points (Fig. 3a). After subtraction of the base line, the background-
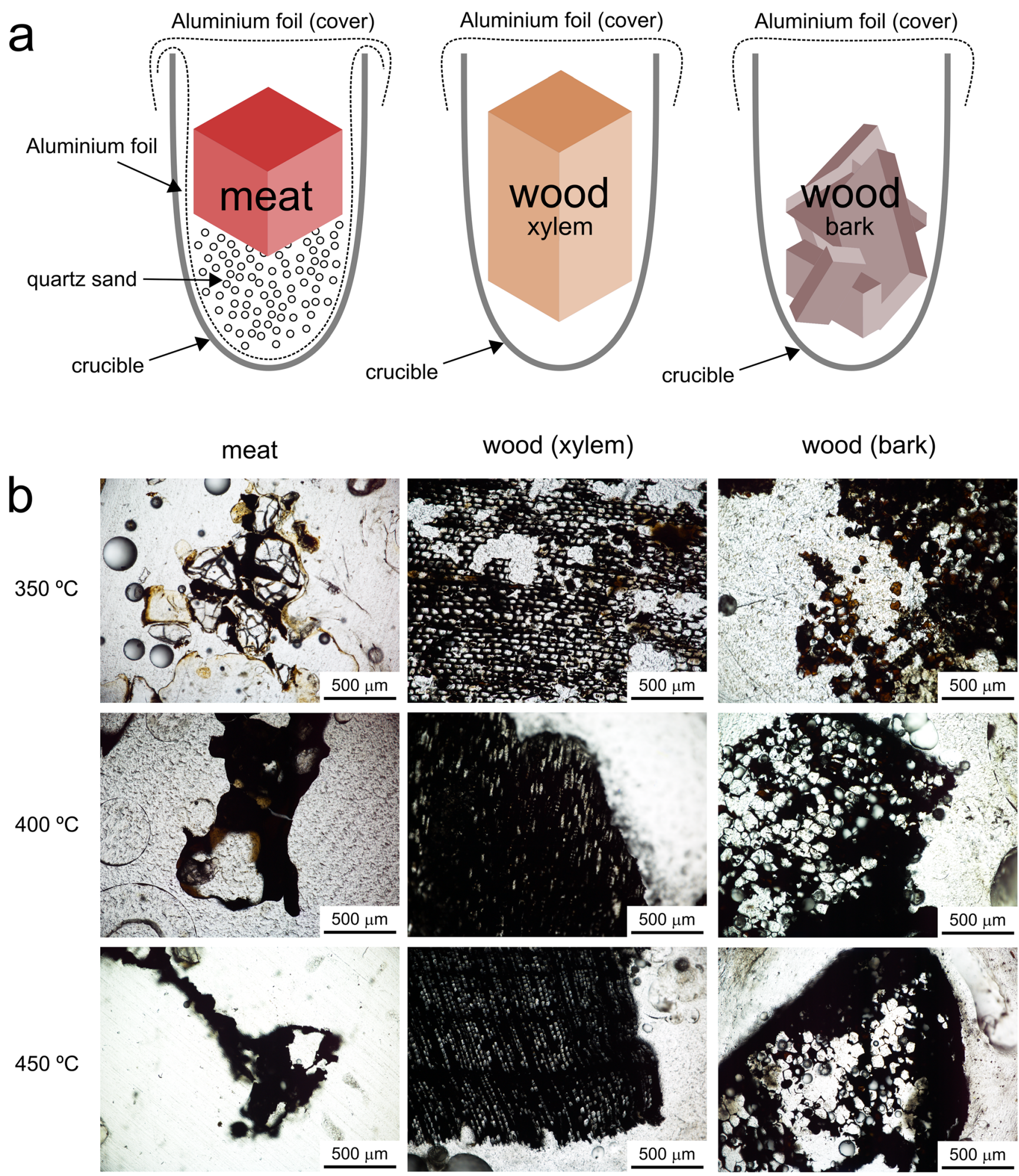

Fig. 1 Experimental furnace samples: a setup of the experiment and $\mathbf{b}$ resulting thin sections 
Modern
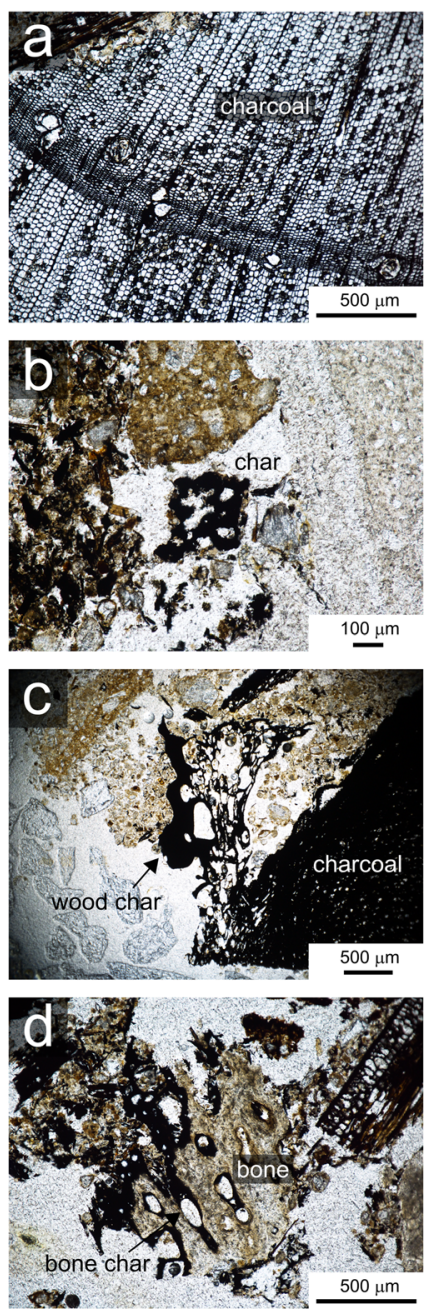

Axlor
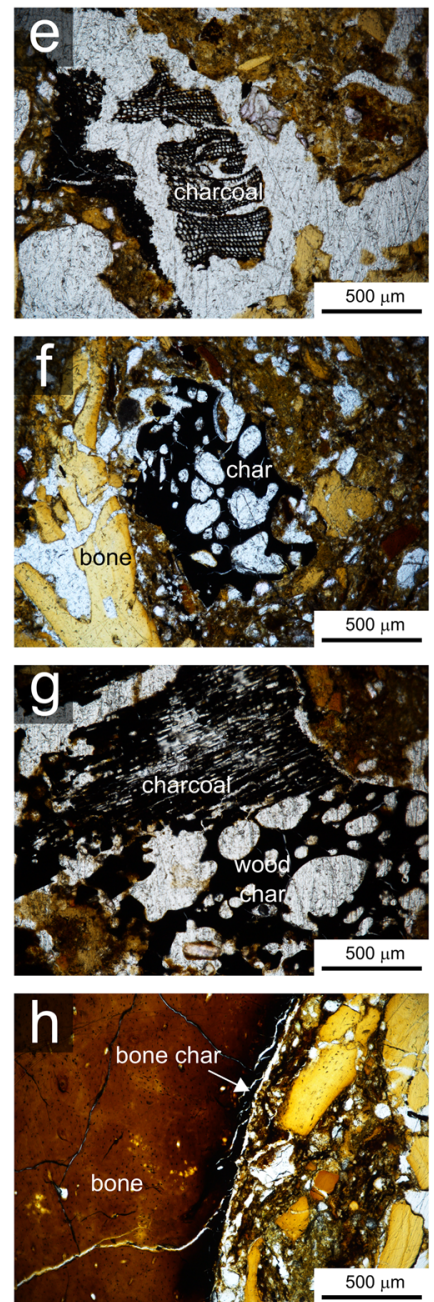

Cvrena Stijena
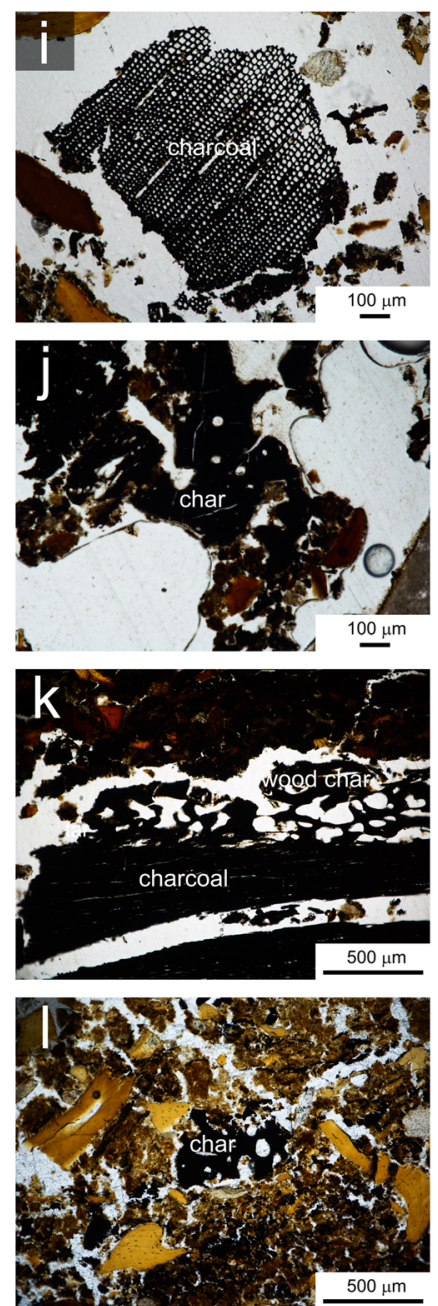

La Roche-à-Pierrot
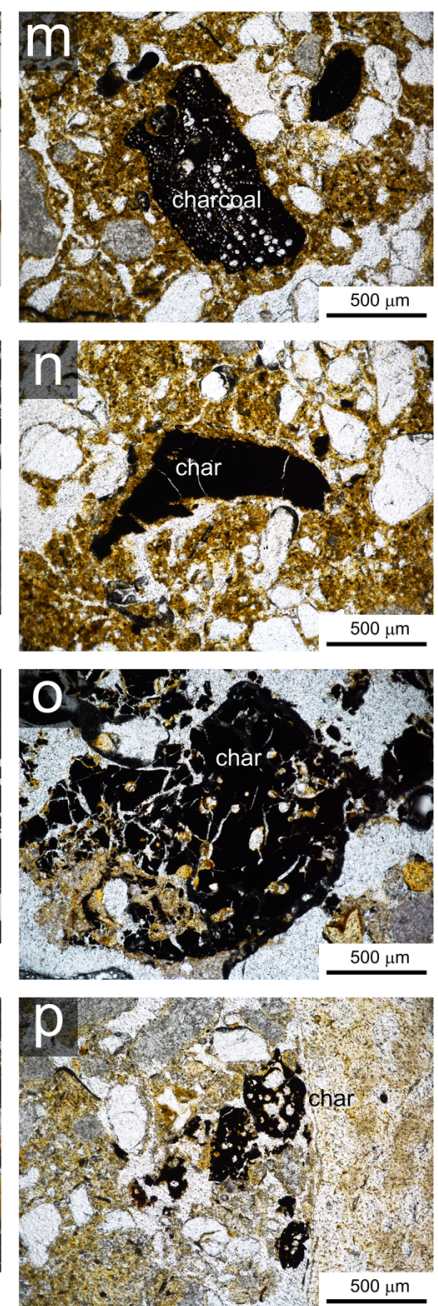

Fig. 2 Microphotographs of unknown samples showing examples of charred fragments identified through micromorphology as charcoal, char, wood char and bone char: a-d modern (NFT) samples, $\mathbf{e}-\mathbf{h}$ Axlor samples, $\mathbf{i}-\mathbf{l}$ Cvrena Stijena samples and $\mathbf{m}-\mathbf{p}$ La Roche-à-Pierrot samples

corrected spectra were fitted with an arbitrary amount (between 6 and 11) of Voight functions (Fig. 3b). The purpose of this fitting procedure was to eliminate any subjective choice of spectral parameters. Voight functions were chosen as they fitted the background-corrected spectra best (compared to Gaussian or Lorentzian functions). The $r^{2}$ value, calculated

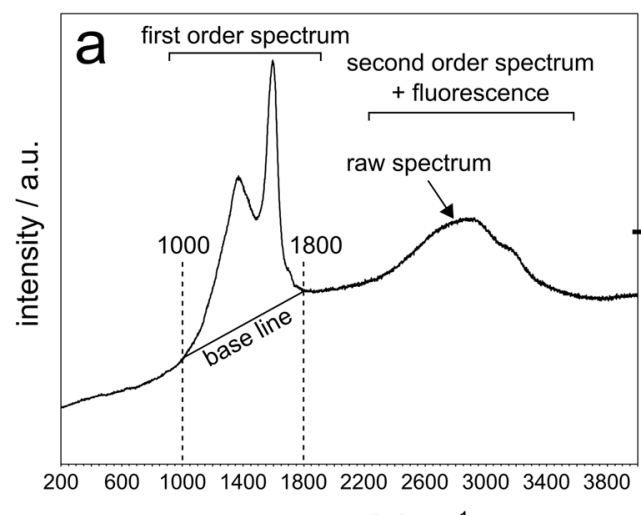

Raman shift / $\mathrm{cm}^{-1}$

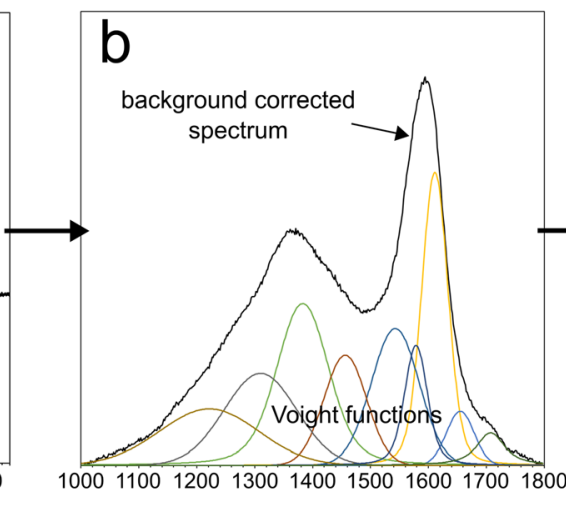

Raman shift / $\mathrm{cm}^{-1}$

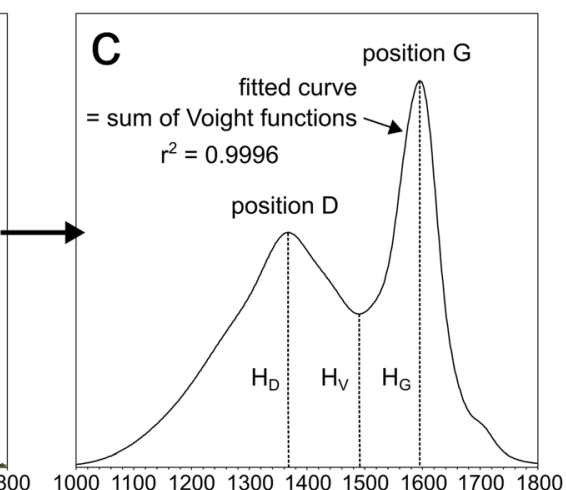

Raman shift / $\mathrm{cm}^{-1}$
Fig. 3 Raman spectral processing and extraction of parameters: a Acquisition of the raw Raman spectrum showing the first- and secondorder spectrum of char. Only the first-order spectrum is considered. A background baseline is chosen between 1000 and $1800 \mathrm{~cm}^{-1}$. b Background-corrected spectrum, fitted with an arbitrary number of Voight functions. $\mathbf{c}$ Measurement of Raman parameters on fitted curve 


\section{REFERENCE SAMPLES}

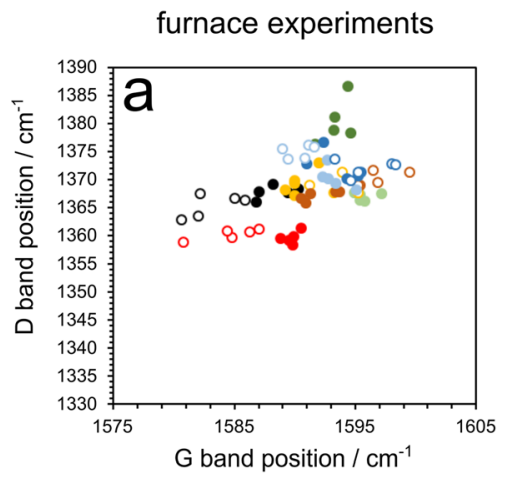

outdoor fire experiments
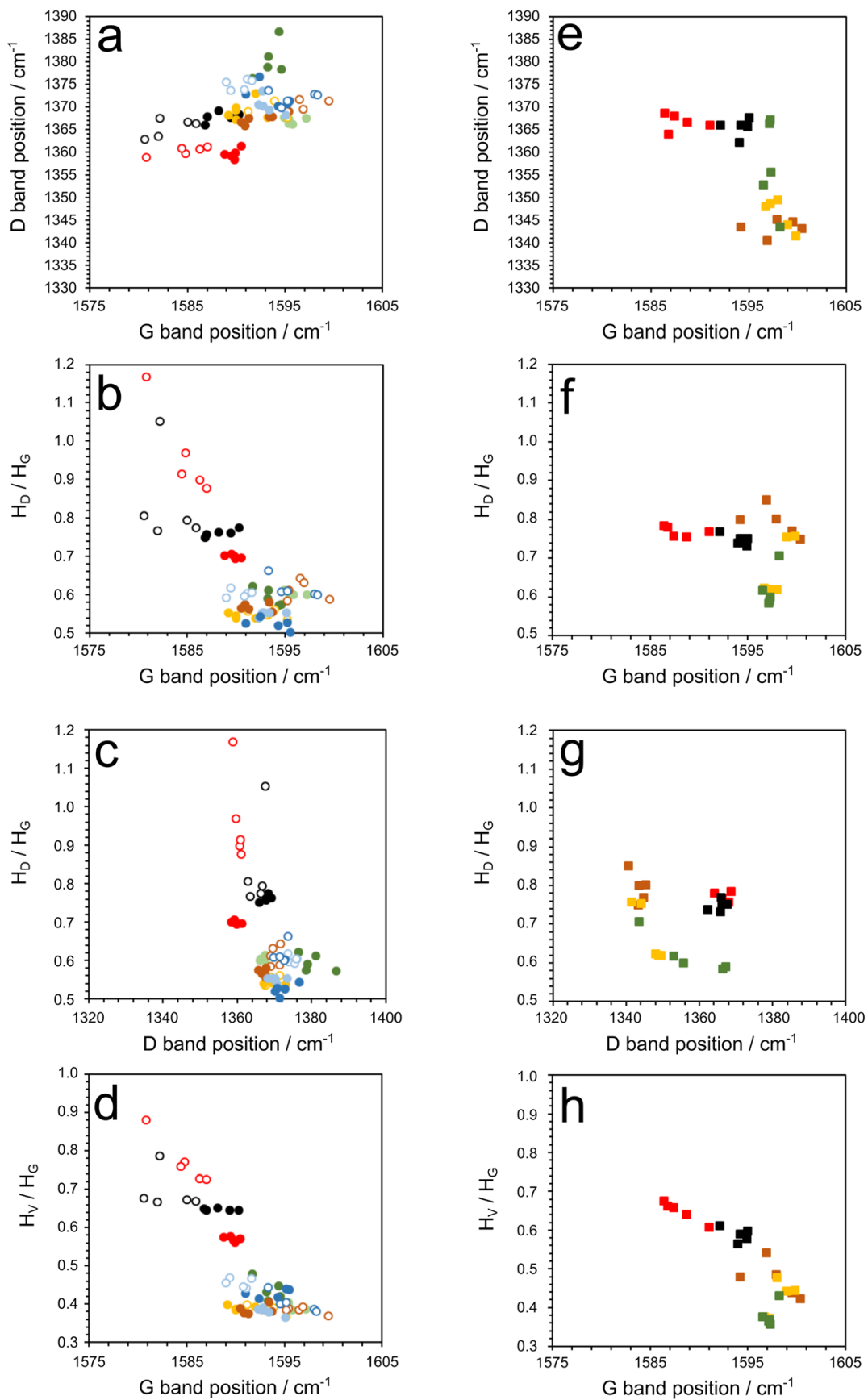
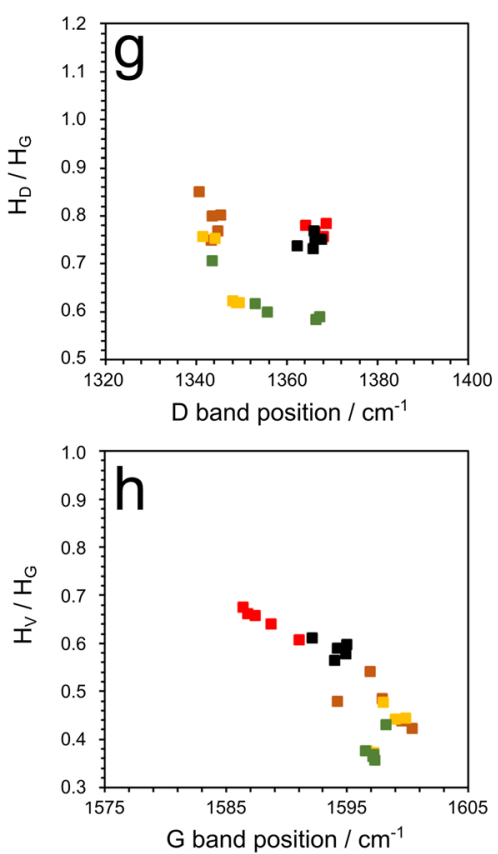

furnace + outdoor fire experiments
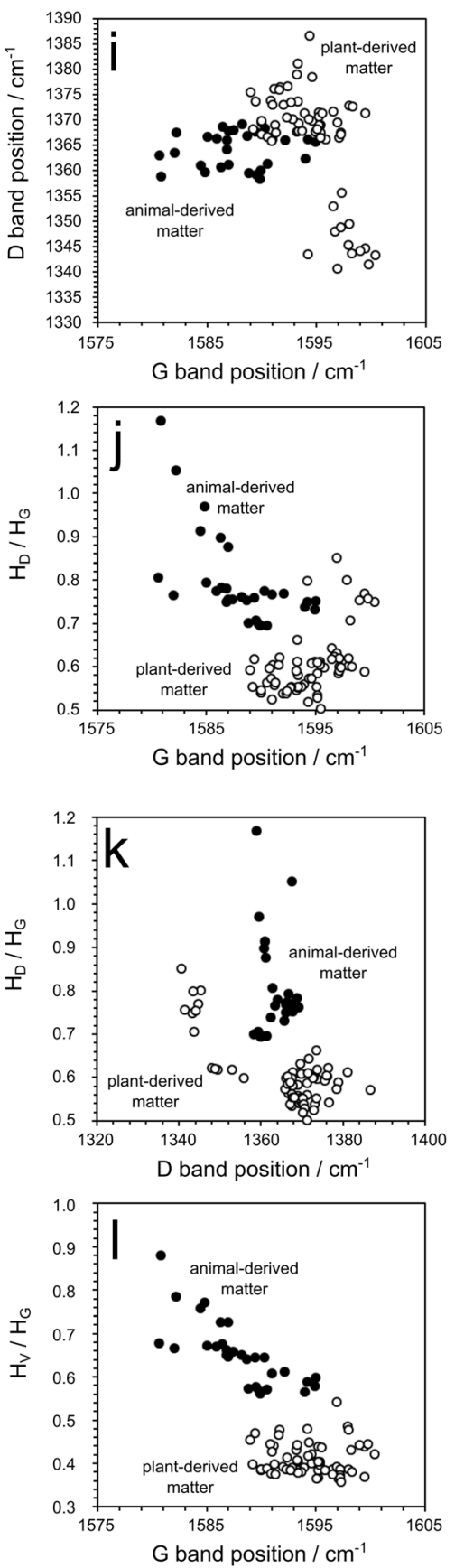

\section{LEGEND}

furnace experiments

\begin{tabular}{|c|c|c|c|}
\hline & unprocessed & in thi & -section \\
\hline 0 & cow meat 400 & - cow meat 400 & - celtis wood xylem 350 \\
\hline o & cow meat 450 & - cow meat 450 & - celtis wood xylem 450 \\
\hline o & pine wood xylem 400 & - pine wood xylem 400 & \\
\hline 0 & pine wood xylem 450 & - pine wood xylem 450 & \\
\hline 0 & pine wood bark 400 & pine wood bark 400 & \\
\hline 0 & pine wood bark 450 & - pine wood bark 450 & \\
\hline
\end{tabular}

outdoor fire experiments furnace +

in thin-section

- trout meat

- rabbit meat

- pine wood (NFT)

- pine wood (EF2)

- celtis wood (NFT) 
Fig. 4 Results of reference samples: a-d samples from laboratoryheating furnace experiments, $\mathbf{e}-\mathbf{h}$ samples from outdoor open-fire experiments, and $\mathbf{i}-\mathbf{l}$ sum of all resulting in a full reference data set

by PeakFit ${ }^{\mathrm{TM}}$, was used to evaluate the quality of the fit. For all data, $r^{2}$ value was above 0.995 , and for the majority of data, it was above 0.999. After successful fitting, five parameters were extracted from the fitted curve (Fig. 3c): the positions of the $\mathrm{D}$ and $\mathrm{G}$ band (in $\mathrm{cm}^{-1}$ ) were defined as the highest points on the fitted curve between 1300 and $1400 \mathrm{~cm}^{-1}$ and 1550 and $1650 \mathrm{~cm}^{-1}$, respectively. The heights of these points (in arbitrary units) were recorded as $H_{\mathrm{D}}$ and $H_{\mathrm{G}}$, respectively. The height of the lowest point between $\mathrm{D}$ and $\mathrm{G}, H_{\mathrm{V}}$ ('V' standing for valley) was recorded as well. From these heights, the following two ratios were calculated: $H_{\mathrm{D}} / H_{\mathrm{G}}$ and $H_{\mathrm{V}} / H_{\mathrm{G}}$.

Analyses that yielded a peak at about $1000 \mathrm{~cm}^{-1}$ were discarded as this peak is present in epoxy resin and indicates an overlap between the Raman spectrum of char and epoxy resin in the thin section. Such an overlap slightly increases the height of the $\mathrm{G}$ band of char due to the presence of another epoxy peak at about $1600 \mathrm{~cm}^{-1}$, thus producing values not representative for char.

\section{Results}

\section{Reference samples}

Raman spectral parameters for the reference furnace samples are presented in Fig. $4 \mathrm{a}-\mathrm{d}$. The $350{ }^{\circ} \mathrm{C}$ samples exhibited too much fluorescence and did not show Raman bands. Plantderived charcoals had $\mathrm{G}$ bands between 1588 and 1600 $\mathrm{cm}^{-1}$, a large spread in D positions, from 1355 to 1390 $\mathrm{cm}^{-1}, H_{\mathrm{D}} / H_{\mathrm{G}}$ ratios between 0.5 and 0.6 and $H_{\mathrm{V}} / H_{\mathrm{G}}$ ratios between 0.3 and 0.5. Compared to this, meat-derived chars showed lower $\mathrm{G}$ bands, between 1580 and $1591 \mathrm{~cm}^{-1}$, a smaller spread in D positions, from 1355 to $1370 \mathrm{~cm}^{-1}$, larger $H_{\mathrm{D}} / H_{\mathrm{G}}$ ratios between 0.65 and 1.2 and larger $H_{\mathrm{V}} / H_{\mathrm{G}}$ ratios between 0.5 and 0.9 . Both $H_{\mathrm{D}} / H_{\mathrm{G}}$ and $H_{\mathrm{V}} / H_{\mathrm{G}}$ ratios allowed complete separation of plant- and meat-derived char (Fig. 4bd).

When comparing raw unprocessed samples with polished thin sections, the following trends could be observed: plantderived charcoals had higher $\mathrm{G}$ band positions when unprocessed, while animal-derived chars showed lower $\mathrm{G}$ bands (Fig. $4 \mathrm{a}, \mathrm{b}$ ). $H_{\mathrm{D}} / H_{\mathrm{G}}$ ratios were higher for both types when unprocessed but animal-derived samples seemed more affected by this (Fig. 4b, c). $H_{\mathrm{V}} / H_{\mathrm{G}}$ ratios were higher in unprocessed animal-derived char but remained the same for plantderived charcoal (Fig. 4d).

In contrast to the furnace samples, the samples produced in outdoor fire experiments (Fig. $4 \mathrm{e}-\mathrm{h}$ ) had no constraint on temperature. As the Raman spectra of char are sensitive to burning temperature (e.g. McDonald-Wharry et al. 2013; Deldicque et al. 2016), a larger variety in spectral values is expected, compared to the furnace experiment samples. Similar to the furnace samples, plant-derived charcoals in outdoor fires had $\mathrm{G}$ bands between 1593 and $1601 \mathrm{~cm}^{-1}$ and a large spread in D positions but with lower values, from 1340 to $1370 \mathrm{~cm}^{-1} . H_{\mathrm{D}} / H_{\mathrm{G}}$ ratios were higher, between 0.55 and 0.85 , and $H_{\mathrm{V}} / H_{\mathrm{G}}$ ratios had a larger range, from 0.3 to 0.6 . Meat-derived char showed higher values for $\mathrm{G}$ bands, compared to their laboratory counterparts, between 1585 and 1596 $\mathrm{cm}^{-1}$ and a similar spread in D values between 1360 and 1370 $\mathrm{cm}^{-1} . H_{\mathrm{D}} / H_{\mathrm{G}}$ and $H_{\mathrm{V}} / H_{\mathrm{G}}$ ratios were similar to the processed samples, ranging from 0.7 to 0.8 and 0.5 to 0.7 , respectively.

Combining the data of the furnace and outdoor fire experiments resulted in a reference data set for animal- and plantderived char (Fig. 4i-1). This data set was then used to evaluate the results of the unknown samples below.

\section{Unknown samples}

Figure 2 shows a selection of microphotographs of charred fragments in the unknown samples (Table 2). Raman spectral parameters from these and similar charred fragments were plotted on top of the reference data set in Fig. 5 .

In the modern fire samples, charcoal and wood char plot in the plant-derived matter region, while char and bone char plot in the animal-derived matter region (Fig. 5a-d). Wood char and charcoal have similar values for the $G$ position but wood char has higher values for the D position (Fig. 5a).

Unlike modern samples, samples from archaeological fires will have undergone some degree of diagenesis, which could cause degradation of char and have an influence on Raman spectral parameters (see 'Background to Raman spectroscopy of char'). It is thus expected that Raman spectral parameters of char in archaeological samples (Fig. 5e-p) will be somewhat different from char in modern fires. In general, charcoal and wood char plotted in the plant-derived matter region, while bone char plotted in the animal-derived matter region. Char either plotted in the animal-derived or plant-derived region (Fig. 5e-p). Compared to modern samples, charcoal from archaeological fires tended to have higher D values, similar to the values for wood char. All charred fragments in archaeological samples also seemed to have higher $H_{\mathrm{D}} / H_{\mathrm{G}}$ ratios, compared to modern samples (e.g. Fig. 5 g, k).

\section{Other observations}

During the impregnation step of thin-section preparation, air bubbles appeared in the two-component epoxy of the immersed plant-derived furnace samples (Table 1; Fig. 1) and the affected samples felt warm to the touch. This suggests an exothermic reaction took place between the epoxy and sample 
material. This phenomenon was most evident in the pine bark samples.

In most charcoal spectra, a weak band at about $1700 \mathrm{~cm}^{-1}$ was observed (both in modern and archaeological samples). A band at this position has been attributed to the presence of carbonyl $(\mathrm{C}=\mathrm{O})$ groups in lignin or acids (e.g. Francioso et al. 2011). Another weak band at about $2215-2225 \mathrm{~cm}^{-1}$, which could represent nitrile $(\mathrm{N} \equiv \mathrm{N})$ groups (e.g. Socrates 2001) has been observed in some of the animal-derived spectra: in unprocessed cow meat furnace samples (Table 1) and in modern bone char (Table 2).

\section{Discussion}

\section{General discussion}

Within the sample pool of this study, animal-derived matter (e.g. charred meat, bone char) could be easily distinguished from plant-derived matter (e.g. charcoal, wood char), using a few Raman parameters. Plotting the $\mathrm{G}$ band position against the $H_{\mathrm{V}} / H_{\mathrm{G}}$ intensity ratio particularly allowed complete separation of these groups (Figs. 4 and 5). For the present method to be applicable universally to archaeological sites, a few considerations must be made. As mentioned in 'Background to Raman spectroscopy of char', the Raman spectrum of char is sensitive to the temperature of formation and degree of degradation (which for archaeological sediment samples relates to post-depositional processes). Furthermore, as the samples consisted of polished thin sections, possible effects of sample preparation must be taken into account.

In micromorphological thin sections, the molecular structure of its components could be altered by mechanical polishing during sample preparation. It is well known that polishing graphitic carbon changes its Raman spectrum: Polishing induces more defects in its crystal structure and increases the height of the D band relatively to the height of the G band (Vidano and Fischbach 1978; Wang et al. 1989; Beyssac et al. 2003). The influence of polishing on the structure of chars, lacking a crystal structure, is lesser known. Considering the results of the furnace experiments in the present study (Fig. 4a-d), when comparing the raw sample material with their polished equivalents it can be observed that thin-section manufacturing has decreased $H_{\mathrm{D}} / H_{\mathrm{G}}$ rather than increasing it, for both animal-derived char and plant-derived charcoal (Fig. 4b). Nevertheless, there is a consistent bi-modal distribution in Raman parameters between animal- and plantderived matter in all unknown samples (Fig. 5). If polishing had a major influence on the structure of char, we would expect the different char types identified in the unknown samples to have a more similar structure. It can thus be concluded that polishing did not cause the observed differences. This seems logical considering that char and charcoal are already poorly organised carbonaceous materials and mechanical polishing may not decrease their crystallographic order any further (Beyssac et al. 2003). Thin-section manufacturing also entails embedding the sample in resin. The position of the $G$ band in the furnace experimental samples did change with thin-section manufacturing: in animal-derived char, the $G$ band shifted to higher wavenumbers, while in plant-derived charcoal, it shifted to lower wavenumbers (Fig. 4a, b and d). At this moment, it is not clear what caused this shift, neither what caused the drop in $H_{\mathrm{D}} / H_{\mathrm{G}}$. One possibility is that embedding the raw material in resin altered the Raman spectra of our sample in some way. During preparation of the furnace samples, air bubbles were observed forming inside the epoxy during impregnation. This was most evident in the plantderived samples. Perhaps, in those samples, pyrogenic oxygen-enriched compounds inside the sample material reacted with one of the components of the two-component resin, promoting the curation of epoxy. The presence of oxygen-rich compounds is indirectly supported by the observation that plant-derived charcoal spectra regularly show a weak band at $1715 \mathrm{~cm}^{-1}$, attributed to carbonyl $(\mathrm{C}=\mathrm{O})$ bonds (e.g. Francioso et al. 2011). In conclusion, thin-section manufacturing does indeed alter the Raman spectra of charred material but not in a way predicted by current understanding of disordered carbon (e.g. Beyssac et al. 2003). In any way, these changes do not appear to be large enough to make the data points of animal- and plant-derived matter overlap (Fig. 4).

The Raman spectrum of graphitic carbon is influenced by its orientation with respect to the laser beam: The relative height of the $\mathrm{D}$ band is at its highest point when the laser beam makes a $90^{\circ}$ angle with the c-axis of the crystal structure, but the positions of D and $\mathrm{G}$ do not change (Wang et al. 1989). Char consists of stacks of PAHs oriented in every direction and no larger than a few nanometre (Heidenreich et al. 1968; Schmidt and Noack 2000). As the Raman laser excites a volume of a few cubic micrometres, it encompasses a large number of such stacks in a single measurement, and it can thus be assumed that any influence of orientation is cancelled out.

It is well known that $H_{\mathrm{D}} / H_{\mathrm{G}}$ in carbonaceous materials is determined by the temperature of formation (e.g. Beyssac et al. 2003). For wood-derived charcoal, Deldicque et al. (2016) have shown that $H_{\mathrm{D}} / H_{\mathrm{G}}$ increases in pinewood chars with burning temperature. In their experiments, the position of the $\mathrm{D}$ band decreases with increasing temperature up to 800 ${ }^{\circ} \mathrm{C}$, and then increases above $800^{\circ} \mathrm{C}$. McDonald-Wharry et al. (2013) observe similar trends for Pinus wood and Phormium leaves: an increase in $H_{\mathrm{D}} / H_{\mathrm{G}}$ up to $900{ }^{\circ} \mathrm{C}$, a decrease in D band position and an increase in $\mathrm{G}$ band position with increasing temperature, as well as a drop in $H_{\mathrm{V}} / H_{\mathrm{G}}$. Smith et al. (2016) observe similar trends in cellulose-derived chars. In the present study, furnace reference samples were constrained to a low temperature $\left(450{ }^{\circ} \mathrm{C}\right.$ and below) but open 
fires were exposed to variable (and locally higher) temperature (Table 1; Mallol et al. 2013a; Buonasera et al. 2019). When comparing the charcoal of the furnace experiments (Fig. 4a-d) with the charcoal of the open fires (Fig. $4 \mathrm{e}-\mathrm{h}$ ), it is indeed observed that the latter have variable $H_{\mathrm{D}} / H_{\mathrm{G}}$ ratios, similar and larger than the furnace experiments. A similar trend can be observed for the position of the $\mathrm{D}$ band (decreasing) and $\mathrm{G}$ band (increasing). The same trends apply to charcoal in

\section{UNKNOWN SAMPLES}
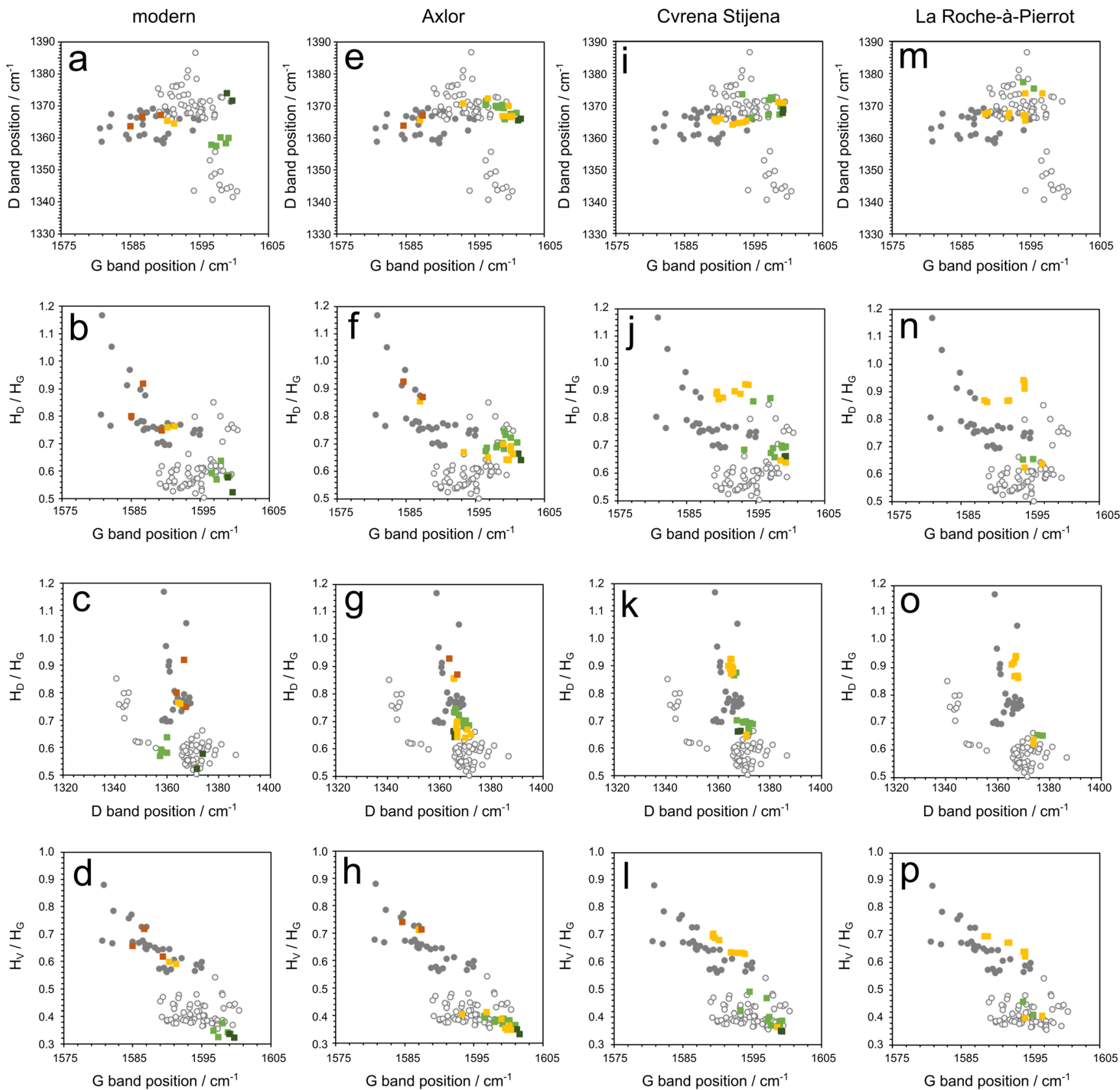

\section{LEGEND}

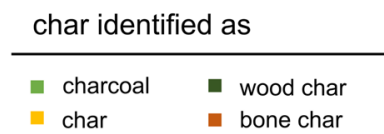

\begin{tabular}{c} 
reference data set \\
\hline animal-derived matter \\
plant-derived matter
\end{tabular}

Fig. 5 Results of unknown samples: a-d modern (NFT) samples, $\mathbf{e}-\mathbf{h}$ Axlor samples, $\mathbf{i}-\mathbf{I}$ Cvrena Stijena samples and $\mathbf{m}-\mathbf{p}$ La Roche-à-Pierrot samples 
modern unknown fires (Fig. 5a-d). We can thus attribute this distribution of data points to burning temperature. For animalderived char, no substantial changes in Raman parameters were observed between experimental furnace and modern samples (Figs. 4 and 5a-d). In summary, even though temperature of formation creates variability in the Raman data, it does not make animal- and plant-derived matter overlap. Note that heat generated by an exothermic reaction occurring during epoxy curation (as observed in plant-derived furnace samples, see 'Other observations') would by itself not be sufficiently high to alter the molecular structure and Raman spectrum of char.

A final consideration is the effect of char degradation through post-depositional processes in archaeological sites. Oxidation and microbial activity are processes able to break down char (Schmidt and Noack 2000). In well-aerated tropical soil environments, charcoal can be significantly degraded in only ten to hundreds of years (Bird et al. 1999). Masiello (2004) suggests that smaller particles may be more easily oxidised, leading to a change in size-fraction over time. Inoue et al. (2017) assume that charcoal fragments from grasslands, produced under higher temperatures are more chemically stable but less physically stable, resulting in their lower rate of residue as fragments in soils as well. Francioso et al. (2011) show that the smallest charcoal size-fractions from a recently burned Pinus pinea forest have the highest $H_{\mathrm{D}} / H_{\mathrm{G}}$ ratio. In the present study, $H_{\mathrm{D}} / H_{\mathrm{G}}$ values of archaeological char and charcoal are higher compared to modern samples (Fig. 5e-p). Based on the above studies, this would thus correspond to a higher temperature of formation, which would make these fragments chemically more stable (thus likely to be preserved), but physically less stable (thus likely to turn into smaller fragments over time). As smaller charcoal size fractions are also correlated with higher $H_{\mathrm{D}} / H_{\mathrm{G}}$ ratio, we can thus hypothesise that this explains the trends observed. We suggest that compared to modern samples, larger char fragments from archaeological sites have been broken down over time, increasing $H_{\mathrm{D}} / H_{\mathrm{G}}$. However, this effect does not obscure the difference between animal- or plant-derived samples.

In conclusion, the above paragraphs establish that the bimodal distribution that allows animal- and plant-derived matter to be distinguished by Raman spectroscopy is not caused by sample preparation, sample setup, burning temperature or post-depositional processes. The differences can thus be considered as representative of a true difference in molecular structure between animal- and plant-derived charred matter.

\section{Implications for micromorphology and archaeology}

How does Raman spectroscopy compare to traditional micromorphology for classifying char fragments as 'animal derived' and 'plant derived'? All fragments that were unambiguously identified through micromorphology as being of animal- or plant-derived origin (i.e. those fragments labelled as 'bone char', 'charcoal' and 'wood char') plotted in the corresponding regions of the Raman reference data set (Fig. 5). This supports the validity of this data set. Only fragments labelled as 'char' plotted either in the animal- or plant-derived region. This is not surprising as 'char' was defined as loose fragments with a vesicular drop-like morphology, cracks and no clear cellular structure (see 'Micromorphology'). As stated in the 'Introduction', this morphology type has previously been interpreted as either animal- (fat-)derived char (Goldberg et al. 2009) or plant-derived tar (Huisman et al. 2019). Herein lies an explanation for the results; char plotting in the animal-derived region, being derived from fat or meat, and char plotting in the plant-derived region, derived from tar or from other anatomical parts of vegetative matter. Raman spectroscopy thus appears to be a great complement to micromorphology in archaeological contexts where ambiguity exists concerning the origin and nature of char fragments.

Finally, the results of the present study may be significant for the three archaeological sites considered in this study (Axlor, Cvrena Stijena, La Roche-à-Pierrot; Table 2; Figs. 2 and 5). These sites are currently under geo-archaeological microstratigraphic investigation and in each case, characterising the microscopic char components is key. The sampled contexts represent Middle Palaeolithic occupation surfaces with remains of anthropogenic combustion, as evidenced by the presence of burned bone and charcoal fragments. The results of this study suggest that, despite them being contexts with abundant burned bone, the three sites preserve microscopic char fragments derived from burning of both animal and plant matter. This information will gain behavioural meaning when contextualised in forthcoming geo-archaeological analyses. For now, the data raises a few issues that motivate further investigation. The Axlor and Crvena Stijena deposits, which both contain abundant charcoal, burned and unburned bone fragments, preserve common microscopic wood char fragments resembling tar-as described by Huisman et al. (2019). Further multi-proxy micro-contextual investigation of the combustion contexts is necessary to approach hearth function and elucidate whether this alleged tar is a natural fuel by-product or may be artificially produced. Neanderthal artificial tar production has previously been proposed in several publications (Boëda et al. 2008; Degano et al. 2019; Niekus et al. 2019). However, Raman spectra of wood tars typically show strong fluorescence or an absence of Raman bands (e.g. Tóth et al. 2018) and our wood char spectra clearly showed G and D bands. Further research is thus required to better understand the possible origins of these fragments. Fragments identified as char are predominantly plant derived in Axlor, while they are predominantly animal derived in Crvena Stijena (Fig. 5). In the latter site, Jambrina-Enríquez et al. (2019) have recently suggested the presence of both animal-fat and wood-oil 
combustion residues as evidenced by compound-specific carbon isotope analyses of lipids. In their study, they observe an isotopic signature attributed to animal-fat residues in stratigraphic layer BL8, while a signature in between animal-fat and wood-oil residues was detected in layers BL10 and BL11. Our corresponding Raman data (Fig. 5i-1) indeed show the presence of three microscopic animal-derived char fragments and one plant-derived charcoal fragment in BL8 and two plant-derived fragments (charcoal and wood char) in BL11. Further measurements in both stratigraphic layers may strengthen the correspondence between lipid biomarker and Raman analyses. Note also that recent compound-specific carbon isotope data suggests a strong plant-oil signature at Axlor (Jambrina-Enríquez, personal communication). In La Roche-à-Pierrot, the archaeological context investigated here is from Layer EGPF, a deposit rich in burned and unburned bone for which the use of bone as fuel has been previously proposed (Morin 2010). Accordingly, the microscopic char samples from this context are predominantly animal derived (Fig. 5m-p). Only one single fragment labelled char (Fig. 2n) was found to be plant derived. This fragment was found in a thin section that also contained a rare piece of charcoal (Fig. $2 \mathrm{~m}$ ), suggesting it could have broken off of this or another piece. In general, the results seem to support the hypothesis of bones used as fuel (Morin 2010). A more detailed and rigorous Raman study for each of these three archaeological sites provides an exciting prospect for future research.

\section{Conclusions}

In a series of laboratory-furnace heating and outdoor open-fire burning experiments, a distinct difference was observed between Raman spectra of charred meat and charred wood. This difference was also observed in micromorphological thin sections of three archaeological combustion contexts, dating to the Middle Palaeolithic. These results lead us to conclude that:

- Raman spectroscopy is a reliable technique to distinguish animal- from plant-derived charred matter. The distinction can be made most effectively by plotting the position of the $\mathrm{G}$ band and the $H_{\mathrm{V}} / H_{\mathrm{G}}$ intensity ratio against one another.

- The method is applicable on samples of charred matter embedded in micromorphological/petrological thin sections and across a broad range of burning temperatures.

- For the three Middle Palaeolithic archaeological contexts tested, post-depositional processes were not a significant factor.

This study supports the high potential of the multi-proxy, micro-contextual approach in archaeological science and introduces a new high-resolution technique, (micro-)Raman spectroscopy, for the investigation of archaeological combustion contexts. The method presented in this study may solve some of the ambiguities that currently exist in micromorphology, namely the interpretation of some vesicular and amorphous char fragments. It may also help in interpreting charred fragments of unknown origin, without any clear morphological characteristics. As this method is directly applicable on the surface of uncovered thin sections and consists of a singlepoint measurement, it allows for an in situ approach, preserving the broader stratigraphic context.

Supplementary Information The online version contains supplementary material available at https://doi.org/10.1007/s12520-020-01263-3.

Acknowledgments The authors thank Inocencio Rafael Martín Benenzuela for providing access to the Raman instrument at the department of physics and IMN of the University of La Laguna (ULL) in Tenerife, Spain. Tammy Buonasera is thanked for providing a reference sample and proofreading the manuscript. Pedro García Villa is acknowledged for performing an initial microscopic screening of different types of char particles. Comments by two anonymous reviewers improved this manuscript and are greatly appreciated.

Author contributions Glenn Lambrecht: conceptualisation, investigation, methodology and writing (original draft). Caterina Rodríguez de Vera: writing (review and editing). Margarita Jambrina-Enríquez: writing (review and editing). Isabelle Crevecoeur: funding acquisition and resources. Jesus Gonzalez-Urquijo: funding acquisition and resources. Talía Lazuen: resources. Gilliane Monnier: funding acquisition and resources. Goran Pajović: funding acquisition and resources. Gilbert Tostevin: funding acquisition and resources. Carolina Mallol: funding acquisition, project administration and writing (review and editing).

Funding This research was supported by the ERC Consolidator Grant project PALEOCHAR - 648871. Research at the Axlor site is funded by the Spanish Ministry of Science and Innovation (Project PID2019107260GB-I00). Research at Crvena Stijena is funded by the Montenegrin Ministry of Culture, the United States National Science Foundation (NSF-BCS 1758285) and the University of Minnesota Grant-in-Aid of Research. The Collaborative Research Project 'PCR La Roche-à-Pierrot' is funded by the Regional Service of Archaeology from Nouvelle-Aquitaine region and the Charente-Maritime Department, France.

Data availability Not applicable

\section{Compliance with ethical standards}

Conflicts of interest The authors declare that they have no conflict of interest.

Code availability Not applicable

Open Access This article is licensed under a Creative Commons Attribution 4.0 International License, which permits use, sharing, adaptation, distribution and reproduction in any medium or format, as long as you give appropriate credit to the original author(s) and the source, provide a link to the Creative Commons licence, and indicate if changes were made. The images or other third party material in this article are included in the article's Creative Commons licence, unless indicated otherwise in a credit line to the material. If material is not included in the 
article's Creative Commons licence and your intended use is not permitted by statutory regulation or exceeds the permitted use, you will need to obtain permission directly from the copyright holder. To view a copy of this licence, visit http://creativecommons.org/licenses/by/4.0/.

\section{References}

Bernard S, Beyssac O, Benzerara K, Findling N, Tzvetkov G, Brown GE Jr (2010) XANES, Raman and XRD study of anthracene-based cokes and saccharose-based chars submitted to high-temperature pyrolysis. Carbon N Y 48:2506-2516

Beyssac O, Goffé B, Chopin C, Rouzaud JN (2002) Raman spectra of carbonaceous material in metasediments: a new geothermometer. $\mathrm{J}$ Metamorph Geol 20:859-871

Beyssac O, Goffé B, Petitet J-P, Froigneux E, Moreau M, Rouzaud J-N (2003) On the characterization of disordered and heterogeneous carbonaceous materials by Raman spectroscopy. Spectrochim Acta A Mol Biomol Spectrose 59:2267-2276

Bird MI, Moyo C, Veenendaal EM, Lloyd J, Frost P (1999) Stability of elemental carbon in a savanna soil. Glob Biogeochem Cycles 13: 923-932

Boëda E, Bonilauri S, Connan J, Jarvie D, Mercier N, Tobey M, Valladas H, Al-Sakhel H (2008) New evidence for significant use of Bitumen in Middle Palaeolithic technical systems at Umm el Tlel (Syria) around 70,000 BP. Paleo 34:67-83

Braadbaart F, Poole I (2008) Morphological, chemical and physical changes during charcoalification of wood and its relevance to archaeological contexts. J Archaeol Sci 35:2434-2445

Buonasera T, Herrera-Herrera AV, Mallol C (2019) Experimentally derived sedimentary, molecular, and isotopic characteristics of bonefueled hearths. J Archaeol Method Theory 26:1327-1375. https:// doi.org/10.1007/s10816-019-09411-3

Cao X, Pignatello JJ, Li Y, Lattao C, Chappell MA, Chen N, Miller LF, Mao J (2012) Characterization of wood chars produced at different temperatures using advanced solid-state 13C NMR spectroscopic techniques. Energy Fuel 26:5983-5991

Degano I, Soriano S, Villa P, Pollarolo L, Lucejko JJ, Jacobs Z, Douka K, Vitagliano S, Tozzi C (2019) Hafting of Middle Paleolithic tools in Latium (central Italy): New data from Fossellone and Sant'Agostino caves. PLoS One 14:e0213473

Deldicque D, Rouzaud J-N, Velde B (2016) A Raman - HRTEM study of the carbonization of wood: a new Raman-based paleothermometer dedicated to archaeometry. Carbon NY 102:319-329

Dupin A, Sordoillet D, Fréville K, Girardclos O, Gauthier E (2019) The taphonomic characterization of a charcoal production platform. Contribution of an innovative pair of methods: Raman analysis and micromorphology. J Archaeol Sci 107:87-99

Francioso O, Sanchez-Cortes S, Bonora S, Roldán ML, Certini G (2011) Structural characterization of charcoal size-fractions from a burnt Pinus pinea forest by FT-IR, Raman and surface-enhanced Raman spectroscopies. J Mol Struct 994:155-162

Goldberg ED (1985) Black carbon in the environment. Wiley, New York

Goldberg P, Miller CE, Schiegl S, Ligouis B, Berna F, Conard NJ, Wadley L (2009) Bedding, hearths, and site maintenance in the Middle Stone Age of Sibudu Cave, KwaZulu-Natal, South Africa. Archaeol Anthropol Sci 1:95-122

Goldberg P, Berna F (2010) Micromorphology and context. Quat Int 214: $56-62$

Goler S, Hagadorn A, Ratzan DM, Bagnall R, Cacciola A, McInerney J, Yardley JT (2019) Using Raman spectroscopy to estimate the dates of carbon-based inks from Ancient Egypt. J Cult Herit 38:106-117
González-Urquijo JE, Ibáñez-Estévez JJ, Rios-Garaizar J, Bourguignon L (2006) Aportes de las nuevas excavaciones en Axlor sobre le final del Paleolítico Medio. In: Cabrera-Valdés V, Bernaldo de QuirósGuidotti F, Maíllo-Fernández JM (eds) En El Centenario de La Cueva de El Castillo: El Ocaso de Los Neandertales. UNED, Universidad Nacional de Educación a Distancia, pp 269-290

Guo Y, Bustin RM (1998) FTIR spectroscopy and reflectance of modern charcoals and fungal decayed woods: implications for studies of inertinite in coals. Int J Coal Geol 37:29-53

Heidenreich RD, Hess WM, Ban LL (1968) A test object and criteria for high resolution electron microscopy. J Appl Crystallogr 1:1-19

Huisman DJ, Niekus MJLT, Peeters JHM, Geerts RCA, Müller A (2019) Deciphering the complexity of a "simple" mesolithic phenomenon: Indicators for construction, use and taphonomy of pit hearths in Kampen (the Netherlands). J Archaeol Sci 109:104987

Inoue J, Yoshie A, Tanaka T, Onji T, Inoue Y (2017) Disappearance and alteration process of charcoal fragments in cumulative soils studied using Raman spectroscopy. Geoderma 285:164-172

Jambrina-Enríquez M, Herrera-Herrera AV, Mallol C (2018) Wax lipids in fresh and charred anatomical parts of the Celtis australis tree: insights on paleofire interpretation. Org Geochem 122:147-160

Jambrina-Enríquez M, Herrera-Herrera AV, Rodríguez de Vera C, Leierer L, Connolly R, Mallol C (2019) n-Alkyl nitriles and compound-specific carbon isotope analysis of lipid combustion residues from Neanderthal and experimental hearths: identifying sources of organic compounds and combustion temperatures. Quat Sci Rev 222:105899

Kennedy IM (1997) Models of soot formation and oxidation. Prog Energy Combust Sci 23:95-132

Lévêque F, Backer AM, Guibaud M (1993) Context of a Late Neanderthal: implications of multidisciplinary research for the transition to Upper Paleolithic adaptations at Saint Césaire, CharenteMaritime, France. Préhistory Press, Madison

Ligouis B (2017) Reflected Light. In: Nicosia C, Stoops G (eds) Archaeological soil and sediment micromorphology Wiley Blackwell

Mallol C, Hernández CM, Cabanes D, Sistiaga A, Machado J, Rodríguez Á, Pérez L, Galván B (2013a) The black layer of Middle Palaeolithic combustion structures. Interpretation and archaeostratigraphic implications. J Archaeol Sci 40:2515-2537

Mallol C, Hernández CM, Cabanes D, Machado J, Sistiaga A, Pérez L, Galván B (2013b) Human actions performed on simple combustion structures: an experimental approach to the study of Middle Palaeolithic fire. Quat Int 315:3-15

Mallol C, Mentzer SM, Miller CE (2017) Combustion features. In: Nicosia C, Stoops G (eds) Archaeological soil and sediment micromorphology. John Wiley \& Sons Ltd., Chichester, pp 299-330

Masiello CA (2004) New directions in black carbon organic geochemistry. Mar Chem 92:201-213

McDonald-Wharry J, Manley-Harris M, Pickering K (2013) Carbonisation of biomass-derived chars and the thermal reduction of a graphene oxide sample studied using Raman spectroscopy. Carbon NY 59:383-405

Mernagh TP, Cooney RP, Johnson RA (1984) Raman spectra of Graphon carbon black. Carbon NY 22:39-42

Morin E (2010) Taphonomic implications of the use of bone as fuel. Palethnologie 2:209-217

Nicosia C, Stoops G (2017) Archaeological soil and sediment micromorphology. John Wiley \& Sons Ltd., Chichester

Niekus MJLT, Kozowyk PRB, Langejans GHJ, Ngan-Tillard D, van Keulen $\mathrm{H}$, van der Plicht J, Cohen KM, van Wingerden W, van Os B, Smit BI, Amkreutz LWSW, Johansen L, Verbaas A, Dusseldorp GL (2019) Middle Paleolithic complex technology and a Neanderthal tar-backed tool from the Dutch North Sea. Proc Natl Acad Sci U S A 116:22081-22087 
Russo C, Ciajolo A (2015) Effect of the flame environment on soot nanostructure inferred by Raman spectroscopy at different excitation wavelengths. Combust Flame 162:2431-2441

Schmidt MWI, Noack AG (2000) Black carbon in soils and sediments: analysis, distribution, implications, and current challenges. Glob Biogeochem Cycles 14:777-793

Smith E, Dent G (2005) Modern Raman spectroscopy - a practical approach. John Wiley \& Sons Ltd., Chichester

Smith MW, Dallmeyer I, Johnson TJ, Brauer CS, McEwen J-S, Espinal JF, Garcia-Perez M (2016) Structural analysis of char by Raman spectroscopy: improving band assignments through computational calculations from first principles. Carbon NY 100:678-692

Socrates G (2001) Infrared and Raman characteristic group frequencies: tables and charts, 3rd edn. John Wiley \& Sons Ltd., Chichester

Stahlschmidt MC, Miller CE, Ligouis B, Goldberg P, Berna F, Urban B, Conard NJ (2015) The depositional environments of Schöningen 13 II-4 and their archaeological implications. J Hum Evol 89:71-91

Stiner MC, Kuhn SL, Weiner S, Bar-YosefO (1995) Differential burning, recrystallization, and fragmentation of archaeological bone. J Archaeol Sci 22:223-237

Taylor GH, Teichmüller M, Davis A, Diessel CFK, Littke R, Robert P (1998) Organic petrology. Gebrüder Borntraeger, Berlin, Stuttgart

Thomsen C, Reich S (2000) Double resonant Raman scattering in graphite. Phys Rev Lett 85:5214-5217

Tóth A, Hoffer A, Pósfai M, Ajtai T, Kónya Z, Blazsó M, Czégény Z, Kiss G, Bozóki Z, Gelencsér A (2018) Chemical characterization of laboratory-generated tar ball particles. Atmos Chem Phys 18: $10407-10418$
Tuinstra F, Koenig JL (1970) Raman spectrum of graphite. J Chem Phys 53:1126-1130

Vidano R, Fischbach DB (1978) New lines in the Raman spectra of carbons and graphite. J Am Ceram Soc 61:13-17

Vidano RP, Fischbach DB, Willis LJ, Loehr TM (1981) Observation of Raman band shifting with excitation wavelength for carbons and graphites. Solid State Commun 39:341-344

Villagran XS, Strauss A, Miller C, Ligouis B, Oliveira R (2017) Buried in ashes: Site formation processes at Lapa do Santo rockshelter, eastcentral Brazil. J Archaeol Sci 77:10-34

Wang A, Dhamenincourt P, Dubessy J, Guerard D, Landais P, Lelaurain M (1989) Characterization of graphite alteration in an uranium deposit by micro-Raman spectroscopy, X-ray diffraction, transmission electron microscopy and scanning electron microscopy. Carbon NY 27:209-218

Wang Y, Alsmeyer DC, McCreery RL (1990) Raman spectroscopy of carbon materials: structural basis of observed spectra. Chem Mater 2:557-563

Whallon R (2017) Crvena Stijena in cultural and ecological context: multidisciplinary archaeological research in Montenegro. Montenegrin Academy of Sciences and Arts, National Museum of Montenegro, Montenegro

Zimmerman AR, Mitra S (2017) Trial by fire: on the terminology and methods used in pyrogenic organic carbon research. Front Earth Sci Chin 5:95

Publisher's note Springer Nature remains neutral with regard to jurisdictional claims in published maps and institutional affiliations. 